\title{
ABBREVIATIONS OF CASTRO'S WORKS
}

AVH Aspectos del vivir hispánico: Espiritualismo, mesianismo, actitud personal en los siglos XIV a XVI. Santiago de Chile: Cruz del Sur, 1949, 168 pp. Enlarged edition with many cuts and additions of "Lo hispánico y el erasmismo" (1940, 1942). 2d ed. revised with many cuts and additions. Madrid: Alianza, 1970, $167 \mathrm{pp}$.

CCE Cervantes y los casticismos españoles. Madrid-Barcelona: Alfaguara, 1966, $364 \mathrm{pp}$. Includes revised introduction to 1966 edition of La Realidad histórica de España. 2d ed. Edited by Paulino Garagorri with additions and corrections from Castro's papers. Madrid: Alianza-Alfaguara, 1974.

CCL "La Celestina" como contienda literaria (casta y casticismos). Madrid: Revista de Occidente, 1965.

CVQ "Como veo ahora el Quijote." Preliminary study to $\mathrm{M}$. Cervantes Saavedra. El ingenioso hidalgo don Quijote de la Mancha. Part I. Madrid: Ed. Magisterio Español, 1971, pp. 9-102.

DEN Dos ensayos: Descripción, narración, historiografía y Discrepancias y mal entender. México: Ed. Porrúa, 1956, $74 \mathrm{pp}$. First essay is new version of preliminary observations to La Spagna nella sua Realtà Storica. Florence: Sansoni, 1955.

ECD De la edad conflictiva. El drama de la Honra en España y en su Literatura. Madrid: Taurus, 1961, 221 pp. 2d ed., very augmented and corrected, 1963, 279 pp. 3d ed., very revised, 1967. 4th ed., 1972.

ECS Los españoles: cómo llegaron a serlo. Madrid: Taurus, 1965, 297 pp. Revised and amplified edition of Origen. ser $y$ existir de los españoles (1959). Revised and published together with "Español," palabra extranjera: razones $y$ motivos (1970) under the title Sobre el nombre y el quién de los españoles. See $S N Q$. 
ENC De la España que aún no conocía. México: Finisterre, 1972. 3 vols. Vol. 1, 278 pp.; vol. 2, 304 pp.; vol. 3, 276 pp.

EPE "Español," palabra extranjera: razones y motivos. Madrid: Taurus, 1970, 113 pp. Reprinted in Sobre el nombre y el quién de los españoles, 1973. See ECS.

ESH España en su historia. Cristianos, moros y judíos. Búenos Aires: Losada, 1948, 709 pp. See The Structure of Spanish History, English translation with revisions and modifications by Edmund L. King. Princeton: Princeton University Press, 1954, 689 pp. ETC "Erasmo en tiempo de Cervantes," Revista de Filología Española, XVIII (1931), 329-389, 441. Reprinted in Semblanzas y estudios (1956), pp. 145-188, and in Hacia Cervantes (1957 and 1960).

HCer Hacia Cervantes. Madrid: Taurus, 1957. 2d ed., very revised. Madrid: Taurus, 1960, 390 pp. 3d ed., considerably revised, 1967.

IPP Iberoamérica. Su presente y su pasado. New York: The or Dryden Press, 1941, 267 pp. 2d ed., revised and IHC augmented, 1946, 304 pp. 3d ed., revised with the assistance of Raymond $\mathrm{S}$. Willis, and published as Iberoamérica: Su historia y su cultura. New York: Henry Holt and Company, 1954 (reprinted 1963. 1964), vii $+248+1 x x i$ pp. 4th ed., with a new prologue in Spanish by the author and revised by "Jorge Campos" (a pseudonym), New York, London, Toronto: Holt, Rinehart and Winston, 1971, viii $+248+$ lxxi pp.

LEL Lengua, enseñanza y literatura (esbozos). Madrid: Victoriano Suárez, 1924, 335 pp.

LHE "Lo hispánico y el erasmismo," Revista de Filología Hispánica (Buenos Aires), II (1940), 1-34 (Part 1); IV (1942), 1-66 (Parts 2 \& 3). Separate printing with "Los prólogos del Quijote," Buenos Aires: Instituto de Filología, 1942, 126 pp. Revised and included in Aspectos del vivir hispánico, 1949, 1970.

OSE Origen, ser y existir de los españoles. Madrid: Taurus, 1959, 175 pp. Revised and augmented, with title Los españoles: cómo llegaron a serlo, 1966. 
PCer El pensamiento de Cervantes. Madrid: Hernando, 1925, 406 pp. (Junta para Ampliación de Estudios. Centro de Estudios Históricos. RFE. Anejo VI). Revised edition, augmented, with notes by the author and Julio Rodríguez-Puértolas. Madrid-Barcelona: Ed. Noguer, 1972, 410 pp.

PLR La peculiaridad lingüística rioplatense y su sentido histórico. Buenos Aires: Losada, 1941, 159 pp. 2d ed., very revised, Madrid: Taurus, 1961, $150 \mathrm{pp}$.

RHE La realidad histórica de España. México: Ed. Porrúa, 1954, 684 pp. New version of España en su historia, 1948. Both the Realidad and España are included in the English translation, The Structure of Spanish History, 1954. Revised edition, 1962, 479 pp. Limited edition of 100 copies with new prologue, 1965. The 1962 edition appeared with the addition of the new prologue again in 1966 (pagination of the prologue is $3-41$, the same as the text). To avoid confusion (!) I have used the 1962 text (RHE 1962) and where specific reference is made to the prologue, $I$ have used used the 1966 text ( $R H E$ 1966). The prologue was also reprinted with revisions as "Más sobre el pasado de los españoles," in Cervantes y los casticismos españoles (1967), pp. 185-253. All later editions of RHE (1962) contain the 1965 prologue and text without modifications: 1967, 1971, 1973, 1975. English trans. The Spaniards: An Introduction to their History with revisions and additions, 1971; see $S I H$.

SAN Santiago de España. Buenos Aires: Emecé, 1958, $152 \mathrm{pp}$.

SEE Semblanzas y estudios españoles. Homenaje a Américo Castro de sus ex-alumnos de Princeton University. Princeton, N.J.: Insula, 1956, 440 pp. Bibliography by Albert Brent and Robert Kirsner; selection of texts and notes, preliminary notes by Juan Marichal. Contains selections later published in Hacia Cervantes, 1957.

SIH The Spaniards. An Introduction to their History, trans. Willard F. King and Selma L. Margaretten. Berkeley, 
xviii ABBREVIATIONS OF CASTRO'S WORKS

Los Angeles, and London: The University of California Press, 1971, $628 \mathrm{pp}$. Contains material from The Structure of Spanish History and La realidad histórica de España, 1962 and 1966 eds., with additions of preface, chapters $i$, xii, and xiv and addendum and appendix.

SNQ Sobre el nombre y el quién de los españoles. Madrid: Taurus, 1973, 406 pp. Contains Español: palabra extranjera (1970) and Los españoles: cómo llegaron a serlo (1965) with new material and prologue by Rafael Lapesa.

SSH The Structure of Spanish History, trans. Edmund L. King. Princeton: Princeton University Press, 1954, 689 pp. Based on España en su historia, revised and augmented. Later included in part in The Spaniards, 1971.

STE Santa Teresa y otros ensayos. Madrid: Historia Nueva, 1929, $278 \mathrm{pp}$. New edition with cuts and additions published as Teresa la santa y otros ensayos. Madrid: Alfaguara, 1972, $321 \mathrm{pp}$.

VLV Vida de Lope de Vega (1562-1635), in collaboration with Hugo A. Rennert. Madrid: Sucesores de Hernando, 1919, 562 pp. 2d ed., with additions by A. Castro and F. Lázaro Carreter, Salamanca: Anaya, $584 \mathrm{pp}$.

Less frequently cited works by Américo Castro for which no abbreviations are given:

La enseñanza del español en España, Madrid: Victoriano Suárez, 1922,109 pp.

Les grands romantiques espagnols. Introduction, translation, and notes by Américo Castro. Paris: La Renaissance du Livre, 1922, 176 pp. (Les Cent Chefs-d'oeuvre Étrangers, no. 72)

Cervantès. Paris: Les Editions Rieder, 1931, 80 pp. (Maîtres des Littératures, XI.)

Españoles al margen. Madrid: Ed. Júcar, 1973, 193 pp. with prologue by Pedro Carrero Eras. It contains the following selection: "El pueblo español" (Previously published in Esa 
gente de España, 7 ensayos de Américo Castro, Raúl Morodo, Sergio Vilar, et al., Costa-Amic, editor; Mexico, 1965), reprinted in ENC, III, 11-31; "Algunos aspectos del siglo XVIII (Introducción metódica)," previously published in $L E L$, pp. 291-333; "Jovellanos," previously published in "El Sol" (Madrid, July 21, 1933), reprinted in SEE, pp. 405-411, and in ENC, II, 203-210; "Francisco Giner," previously published in "La Nación" (Buenos Aires, June 6, 1937), reprinted in $S E E$, pp. 413-419, and in ENC, II, pp. 213-220; "Manuel B. Cossío," previously published in "Revista de Pedagogía" (Oct. 1935), reprinted in SEE. pp. 421-435, and in ENC. II, pp. 223-241; "Esbozos pedagógicos (La organización de las Facultades de Letras)," previously published in "El Sol" (Madrid, Summer 1920), reprinted in $L E L$; "De grata recordación (Juan Valera y Alberto Jiménez)," previously published in "Cuadernos" (Paris, No. 22, January, 1957), reprinted in $E N C$. II, pp. 245-264; "Homenaje a una sombra ilustre (Una residencia de estudiantes)," previously published in "Residencia" (México, December, 1963), reprinted in ENC. II, pp. 267-272; "Minorias y mayorias," previously published in "El Nacional" (Caracas, February 5, 1953).

Wherever possible I have included references to the two English translations alongside the Spanish, but not in parenthesis because in many cases it is not a direct translation: $E S H=S S H: R H E(1954,1962,1966)=S I H$. 
